\section{UJMM

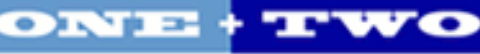

Volume 4 | 2012 Spring

\section{Undergraduate Journal of Mathematical}

Modeling: One + Two

2012

\title{
Overfishing of the Common Snook
}

Allison Ashcroft

University of South Florida

\author{
Advisors: \\ Arcadii Grinshpan, Mathematics and Statistics \\ Robert Muller, Fish and Wildlife Conservation Commission \\ Problem Suggested By: Robert Muller
}

Follow this and additional works at: https://digitalcommons.usf.edu/ujmm

Part of the Mathematics Commons

UJMM is an open access journal, free to authors and readers, and relies on your support:

Donate Now

\section{Recommended Citation}

Ashcroft, Allison (2012) "Overfishing of the Common Snook," Undergraduate Journal of Mathematical Modeling: One + Two: Vol. 4: Iss. 2, Article 4.

DOI: http://dx.doi.org/10.5038/2326-3652.4.2.4

Available at: https://digitalcommons.usf.edu/ujmm/vol4/iss2/4 


\title{
Overfishing of the Common Snook
}

\begin{abstract}
The chief aim of this project is to determine if the populations of the common snook, Centropomus Undecimalis, in the Atlantic and Gulf coast are being affected by overfishing. This is established by evaluating the intrinsic rate of change for these populations and their carrying capacities. It turns out that the carrying capacity for the population of the Atlantic coast is approximately one million snook and its intrinsic rate is 0.00621 , while the carrying capacity of the Gulf coast's population is 2.9 million snook and its intrinsic rate is 0.00165 . The decline of both populations is most likely due to the overfishing; however Gulf coast's population of the snook is decreasing at a faster rate than in the Atlantic.
\end{abstract}

\section{Keywords}

Common Snook, Overfishing, Carrying Capacity

Creative Commons License

(c) (i) (3)

This work is licensed under a Creative Commons Attribution-Noncommercial-Share Alike 4.0 License. 


\section{TABLE OF CONTENTS}

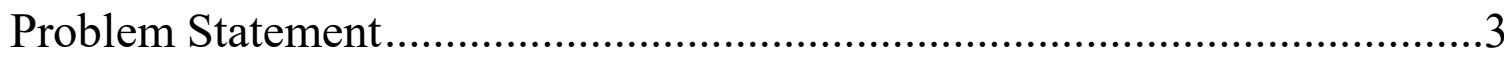

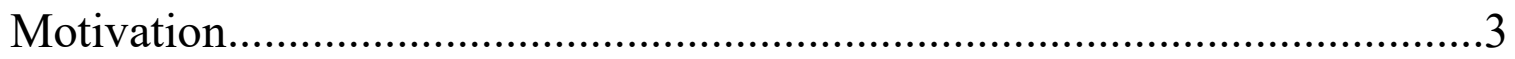

Mathematical Description and Solution Approach .........................................3

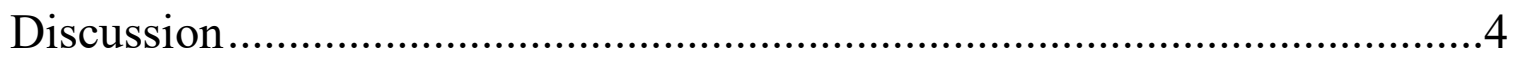

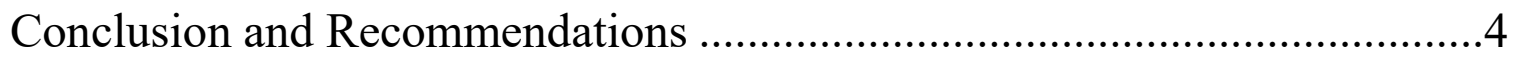

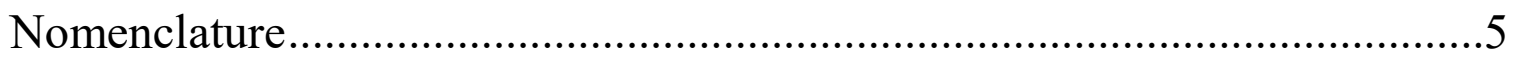

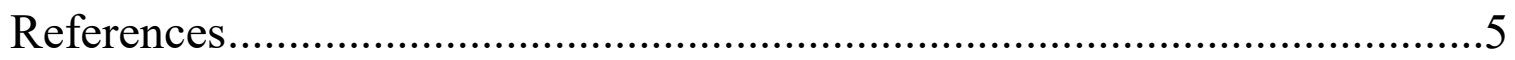

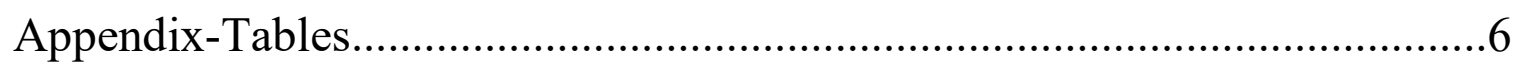

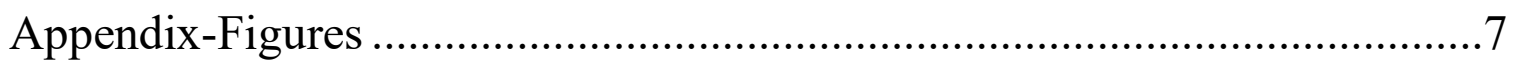




\section{PROBLEM STATEMENT}

Assess the impact of overfishing on the populations of common snook of the Atlantic coast and the Gulf coast of Florida.

\section{MOTIVATION}

Common snook is a fish found in the coastal waters of Florida. Snook is very popular for sport and subsistence fishing, both of which put an increased pressure on its population. Snook has

been declared a game fish, and so its commercial fishing and sale are prohibited. The population levels are mostly controlled by setting the fishing limits, which are determined from the estimates of its current population size.

Currently, common snook fishing is prohibited between December 15 and January 31 statewide in Florida and a bag limit of 1 or 2 fish per person per day depending on the area is imposed. The caught fish cannot be shorter than 28 " or longer than 32 " in the Atlantic; in the Gulf, they cannot be shorter than 28" or longer than 33" (Fish and Wildlife Conservation Commisson. J.F. Griffin.).

\section{MATHEMATICAL DESCRIPTION AND SOLUTION APPROACH}

We use snook population data for both Atlantic and Gulf coasts of Florida collected from 1896 until 2010 (see Tables 1-2 and Figures 1-2) to predict carrying capacities and growth rates of both populations. Initially, we've tried to apply the logistic growth model,

$$
N(t)=\frac{K}{1+\left(\frac{K}{N_{o}}-1\right) e^{-r t}}
$$


where $N_{0}$ is the initial population, $K$ is the carrying capacity, and $r$ is the intrinsic growth rate. However, we were unable to get a good estimate for $K$ and $r$ in the Equation 1 for the provided data using the Excel's solver tool. Instead, we decided to use the following model

$$
N(t)=\frac{K}{1+\left(\frac{K-N(t-1)}{N(t-1)}\right) e^{-r t}}
$$

which estimates the next year's population based on the population for the current year. The values of $K$ and $r$ were again estimated using the solver tool. The initial value of $K$ for this calculation was chosen to be the double of the mean $(1,303,007$ for the population in the Atlantic and 2,869,883 for the population in the gulf); we chose 0 for the initial value of $r$.

\section{DISCUSSION}

We have estimated that the carrying capacity of the snook population in the Atlantic is $996,778.7$ and its intrinsic rate is 0.00621 . The carrying capacity of the Gulf's population is $2,869,958.03$ and its intrinsic rate is 0.00165 . In the Atlantic, the snook population has been decreasing slowly since 1992; in the Gulf, the population fluctuated from 1989 until 2000 and then dramatically declined.

\section{CONCLUSION AND RECOMMENDATIONS}

It is clear that the population of the common snook in the Gulf is declining more rapidly than its population in the Atlantic. However, it seems that both populations are being overfished.

Furthermore, there may be other factors that impact the population of the snook (see (Mote Marine Laboratory) (Muller and Taylor)). For example, the shallow, coastal regions 
inhabited by snook are affected by pollution like urban and agricultural runoff. Dolphins, birds, and larger fish pray upon snook and it competes with other species for space and nutrition. In 2010, snook populations suffered due to a deep freeze from January to February and dead snook were being pulled out of the water by the thousands. Incorporating other data into our model (such as release rates) may help to better assess and predict the population of snook in the future.

\section{NOMENCLATURE}

\begin{tabular}{cc}
\hline Symbol & Meaning \\
\hline $\boldsymbol{N}(\boldsymbol{t})$ & Snook's population at the time $t$ (in years) \\
$\boldsymbol{N}_{\mathbf{0}}$ & Initial population \\
$\boldsymbol{K}$ & Carrying capacity \\
$\boldsymbol{r}$ & Intrinsic rate \\
\hline
\end{tabular}

\section{REFERENCES}

Fish and Wildlife Conservation Commisson. J.F. Griffin. "Basic Recreational Saltwater Fishing Regulations." 3 May 2012. eregulations. <http://www.eregulations.com/>.

Larson, Ron, Robert Hostetler and Bruce Edwards. Calculus. 8th Edition. Boston, MA: Houghton Mifflin Company, 2005.

Mote Marine Laboratory. "New Grant to Support Snook." 25 January 2011. Mote Newsroom.

Muller, Robert G and Ronald G Taylor. "Stock Assessment Update of Common Snook, Centropomus Undecimalis." 31 January 2006. Fish and Wildlife Conservation Commission: Fish and Wildlife Research Institute. 3 May 2012. 


\section{APPENDIX-TABLES}

\begin{tabular}{cc}
\hline Year & Population \\
\hline 1986 & 581688 \\
1987 & 723209 \\
1988 & 654179 \\
1989 & 578548 \\
1990 & 649360 \\
1991 & 834893 \\
1992 & 992259 \\
1993 & 931549 \\
1994 & 865707 \\
1995 & 783207 \\
1996 & 742466 \\
1997 & 688213 \\
1998 & 663389 \\
\hline 1999 & 682911 \\
\hline 2000 & 679118 \\
\hline 2001 & 630555 \\
\hline 2002 & 621110 \\
\hline 2003 & 633115 \\
\hline 2004 & 588827 \\
\hline 2005 & 580697 \\
\hline 2006 & 560160 \\
\hline 2007 & 504250 \\
\hline 2008 & 456482 \\
\hline 2009 & 345284 \\
\hline 2010 & 316409 \\
\hline
\end{tabular}

Table 1: Atlantic population of snook from 1986 until 2010. The data is provided by Dr. Robert Muller from the FWC: Fish and Wildlife Research Institute in St. Petersburg, FL.

\begin{tabular}{lc}
\hline Year & Population \\
\hline 1986 & 606846 \\
1987 & 605655 \\
1988 & 945140 \\
1989 & 1167367 \\
1990 & 1452475 \\
\hline 1991 & 1350194 \\
1992 & 1212708 \\
\hline 1993 & 1189455 \\
\hline 1994 & 1295157 \\
\hline 1995 & 1320324 \\
\hline 1996 & 1168693 \\
\hline 1997 & 1372624 \\
\hline 1998 & 1425590 \\
\hline 1999 & 1590628 \\
\hline 2000 & 2001466 \\
\hline 2001 & 1887771 \\
\hline 2002 & 1764112 \\
\hline 2003 & 2420511 \\
\hline 2004 & 2626599 \\
\hline 2005 & 2006222 \\
\hline 2006 & 1699178 \\
\hline 2007 & 1526497 \\
\hline 2008 & 1267498 \\
\hline 2009 & 1052766 \\
\hline 2010 & 918058 \\
\hline
\end{tabular}

Table 2: Atlantic population of snook from 1986 until 2010. The data is provided by Dr. Robert Muller from the FWC: Fish and Wildlife Research Institute in St. Petersburg, FL. 


\section{APPENDIX-FIGURES}

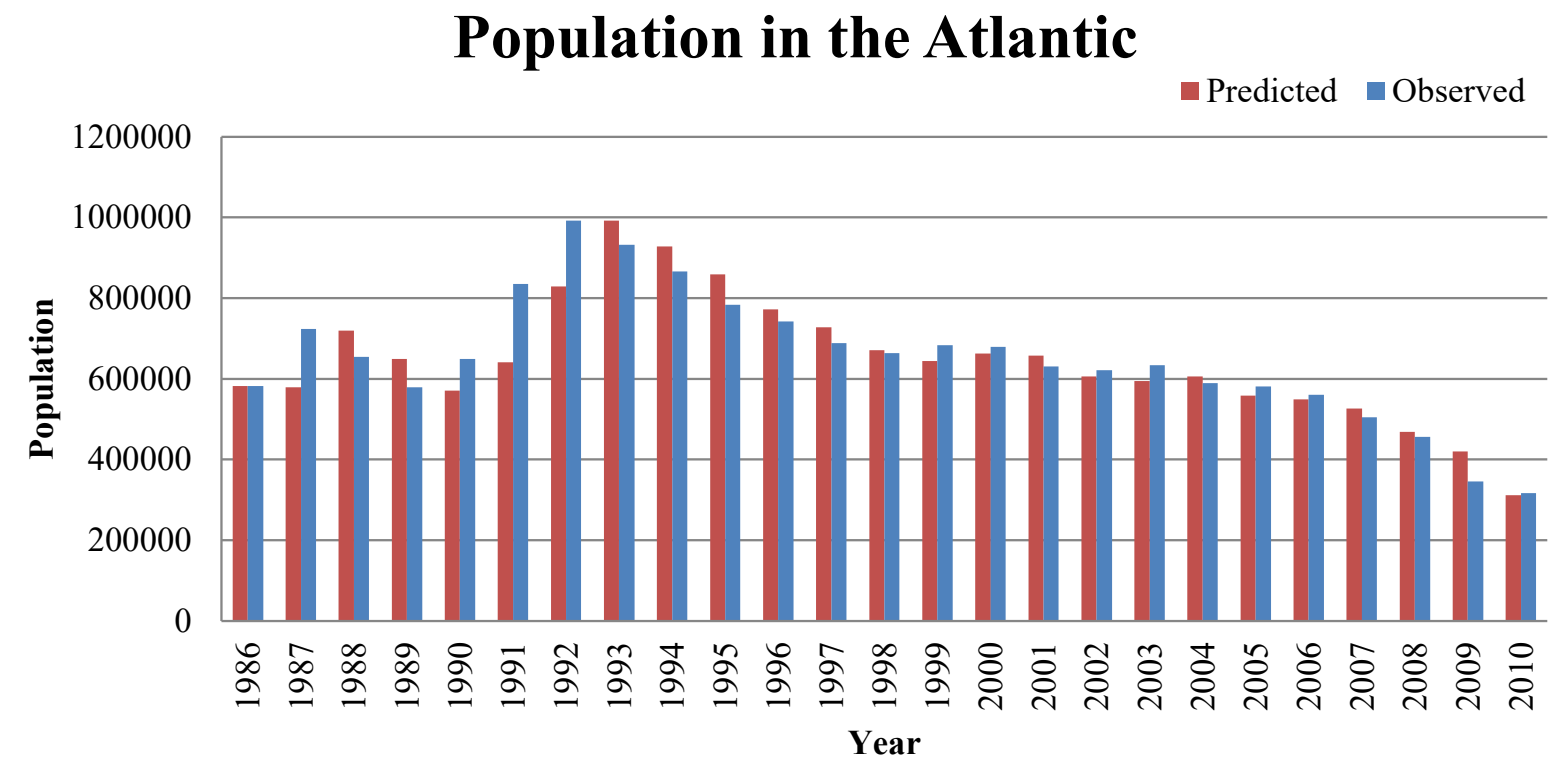

Figure 1: Predicted and observed population size for Atlantic's population of the snook.

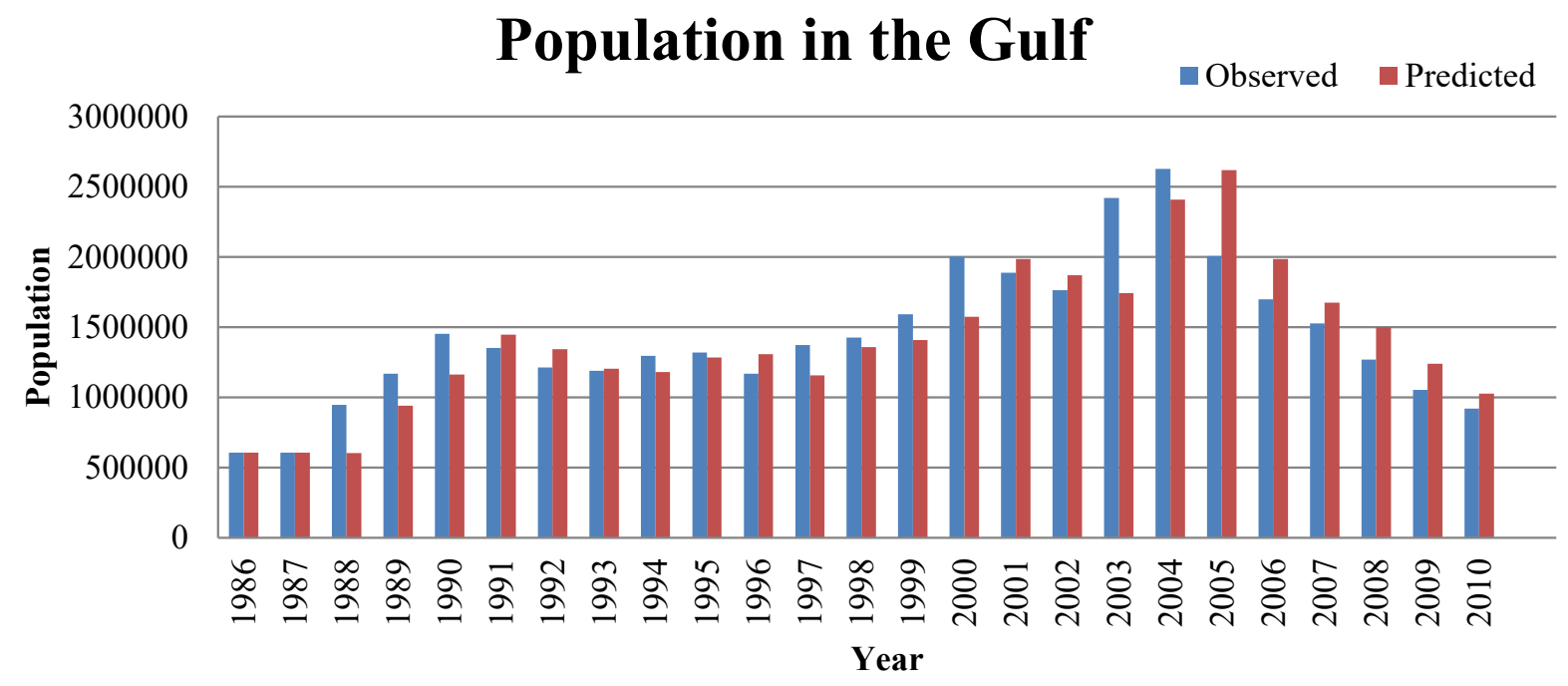

Figure 2: Predicted and observed population size for Gulf's population of the snook. 